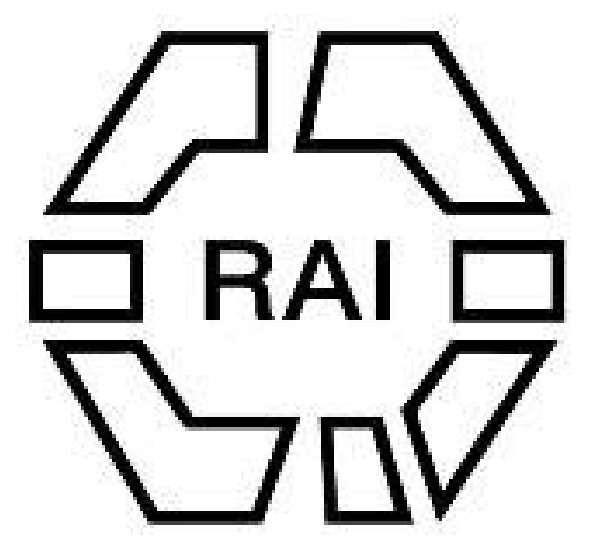

\title{
WILEY
}

\section{Description of a Bronze Flat Celt in the Newbury Museum}

Author(s): Harold Peake and John J. Manley

Source: Man, Vol. 14 (1914), pp. 112-113

Published by: Royal Anthropological Institute of Great Britain and Ireland

Stable URL: http://www.jstor.org/stable/2787458

Accessed: 25-04-2016 23:43 UTC

Your use of the JSTOR archive indicates your acceptance of the Terms \& Conditions of Use, available at

http://about.jstor.org/terms

JSTOR is a not-for-profit service that helps scholars, researchers, and students discover, use, and build upon a wide range of content in a trusted digital archive. We use information technology and tools to increase productivity and facilitate new forms of scholarship. For more information about JSTOR, please contact support@jstor.org.

Royal Anthropological Institute of Great Britain and Ireland, Wiley are collaborating with JSTOR to digitize, preserve and extend access to Man 
the dead are handed over to relatives, the Taumaha ritual is recited over the foods for the funeral feast.

Three summers pass away, the bones are reclaimed from earth or tree, and burned with fire. Prior to such burning certain foods for a ritual feast are cooked in tapu ovens, while the priest extracts the teeth from the skull, ties them to a wand, and then, holding up the wand in his hand, he repeats a certain formula. Then, when the shades of night fall, the bones of the dead are burned.

The second charm is to preserve the life and welfare of the living. Hikurangi is a mountain in the original homeland of the Maori race, a famed and sacred mount, the abode of the Bird of the Sun.

These brief notes comprise all that we have to offer on the subject of cremation among the Maori folk of New Zealand; the custom was never a common one, and was only resorted to under certain circumstances, as we have shown.

For the benefit of non-residents in these isles, it may be as well to state that the practice of cremation has long been discontinued among the Maori, though cases are known in which the bodies of our dead were burned by the hostiles during the late unpleasantness in the 'sixties.

ELSDON BEST.

England : Archaeology.

Peake : Manley.

Description of a Bronze Flat Celt in the Newbury Museum. By

Harold Peake. With a Report on an Analysis of the Alloy by John J. II Manley, Daubeny Laboratory, Magdalen College, Oxford.

The flat celt which is here illustrated belongs to the Borough of Newbury Museum, and was formerly in the museum belonging to the Newbury Literary and

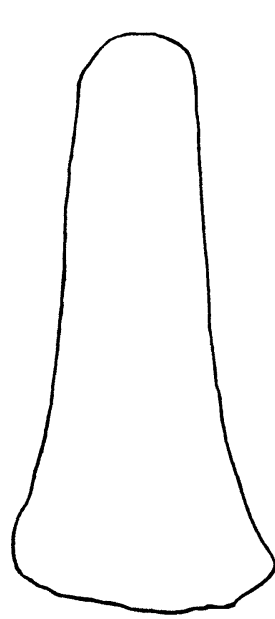

Scientific Institution. It is said to have been found near Newbury, but the exact site of its discovery is unknown.

In a MS. catalogue of the old museum compiled in 1854, by James White Roake, the curator at that time, it is thus described: "I. 63. Three bronze spearheads or celts. Supposed " to have been manufactured and used by the ancient Britons. " Exhumed in the neighbourhood of Newbury. Deposited by "J. W. Roake."

Then follow extracts from the Encyclopadia Britannica. The two other celts are of a later type.

This celt is $170 \mathrm{~mm}$. long, $76 \mathrm{~mm}$. wide at the cutting edge, $34 \mathrm{~mm}$. wide at the other end, and $11.5 \mathrm{~mm}$. thick. Its sides seem to have been hammered so as to exhibit faint traces of flanges; there are no signs of a stop ridge. Its weight was 520 grams, but 3 grams were removed for analysis by Professor H. J. Bowman, and were handed over to Mr. John J. Manley, who has kindly contributed the following account.

H. PEAKE.

\section{The Chemical Composition of the Bronze.}

In December 1911, I received from Professor Bowman 3 grams of drillings which had been removed from the above-named flat bronze celt. These drillings have recently been analysed under my supervision by one of my pupils, Mr. E. A. Berrisford, of Queen's College Oxford. Two perfectly independent analyses were carried out, and, with the object of securing the greatest possible degree of accuracy, all the weighings were effected with a previously fully-tested and highly sensitive long beam Oertling balance, by the methods of reversal and vibration. Beyond stating that every care was taken to exclude the introduction of foreign matter and 
to obtain the separated constituents in a pure condition, it is probably unnecessary to detail the methods of analysis. The results may be conveniently summarised as follows :--

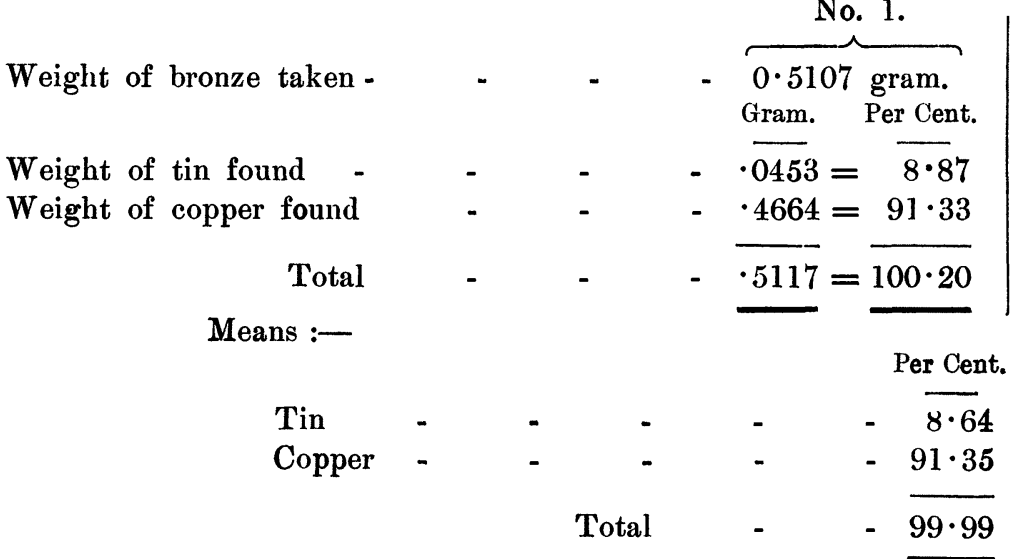

No. 2. $0 \cdot 4410$ gram. Gram. Per Cent. $\overline{0371}=\overline{8 \cdot 41}$ $\cdot 4029=91 \cdot 36$

$\cdot 4400=99 \cdot 77$

It may be observed that in analysis No. 1 , the found "total" is 0.001 grams in excess of the weight of bronze actually taken, whilst in analysis No. 2 the found "total" is deficient by a like amount. These variations are ascribed to unavoidable errors associated with the particular methods of analysis employed. As will be seen, they are equal to \pm 1 part in 500 .

An initial qualitative analysis revealed the presence of a minute trace of iron the quantity of which was too small to be duly estimated. The iron may possibly have been introduced during the operation of drilling.

J. J. MANLEY.

\section{Africa, West.}

"Bori" among the Hausas. By H. R. Palmer.

Palmer.

In a recent work* dealing with Nigerian tribes there is mention of bori 42 dances among the Hausas. The author in a fascinating chapter discusses the origin of bori. It would appear, however, that Dr. Frobenius misconceives in some respects the meaning of the word bori.

He uses such phrases as "The Bori have a religion," "The Bori's religion," "The Bori has . . . been fused with the old clan organisation," "The Bori's " usual appearance in the streets," etc., from which it is to be inferred that he regards bori as people, though in another passage he writes, "Animism is the " religious basis of the Bori, a philosophy which, throngh the agency of spirits or " demons, endues every object, and especially parts of nature such as stones, trees, " and rivers, with a soul."

Bori is a Hausa common noun, and means a sacred and occult force which resides in matter. $\dagger$ It is distinguished from maita, which is more particularly the power exercised by certain persons, maigîu, i.e., wizards or witches, over bori, and the objects in which it is resident, and boka, which is the science of medicine-the science of medicine, however, of the Middle Ages.

The word bori itself seems to be from the same root as the Hausa word borassa, which now means distilled spirits, as opposed to the native palm wine and other similar drinks. The original meaning of borassa may be seen from Professor Masqueray's note on this word-Berber form aurassen.+

* Frobenius, The Voice of Africa, Chap. XXVI.

$\uparrow$ The same idea apparently as the Melanesian mấa.

‡ Quoted by Rinn Berbers, p. 228. 